\title{
Deel I
}

\section{Generiek Raamwerk}

\author{
Zorg en Kosten
}

\section{Algemene Methodiek}

\author{
In opdracht van het \\ Centrum voor VolksgezondheidsToekomstVerkenningen, \\ RIVM
}

Project Integrale Volksgezondheidsmodellering 


\section{Voorwoord}

Bij het Rijksinstituut voor Volksgezondheid en Milieuhygiëne (RIVM) is ten behoeve van de kwantitatieve toekomstverkenningen een Integraal VolksgezondheidsModel (IVM) in ontwikkeling. Aan MERIT is in september 1994 door het RIVM de opdracht gegeven om op korte termijn bij te dragen aan de ontwikkeling van een algemeen methodologische aanpak voor een eerste raming van zorg en kosten met betrekking tot de verschillende ziektecategorieën die in IVM zijn (of worden) opgenomen. Het uitgevoerde onderzoek wordt in dit rapport beschreven.

De voorliggende rapportage bestaat uit twee delen. Het eerste gedeelte geeft de bevindingen weer van een onderzoek naar de ontwikkeling van een dergelijke generieke aanpak. Het tweede gedeelte kan worden beschouwd als de toepassing van de generieke aanpak. Deze toepassing vindt plaats op Coronaire Hartziekten (CHZ).

Graag wil ik een woord van dank richten aan de medewerkers van de afdelingen VTV en CWM van het RIVM voor de veelal prettige manier van samenwerking en steun die ik heb gekregen in de loop van het onderzoek. Hierbij wil ik in het bijzonder noemen Marianne van Genugten, Maarten Postma, Louis Niessen, Wil Vrijsen, Rudolf Hoogenveen, Siem Heisterkamp, René Poos, Harry Verkley, Anneke van den Berg Jeths en Hans Jager. In dit verband wil ik ook Pieter Kramers, hoofd van de afdeling VTV, en Anton van der Giessen, projectleider IVM, bedanken, die mij binnen het kader van de onderzoeksopdracht de ruimte hebben geboden om mijn gedachten over een generieke aanpak vorm te geven en te operationaliseren met behulp van gegevens van de Stichting Informatiecentrum Gezondsheidszorg (SIG).

Een woord van dank is ook verschuldigd aan Corien Gijsbers (MERIT), die de produktie en layout van dit rapport voor haar rekening heeft genomen.

\section{Gijs Boas}




\section{Inhoudsopgave}

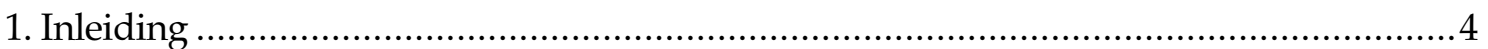

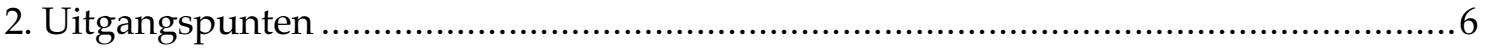

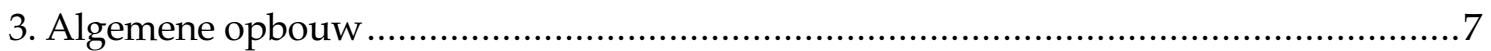

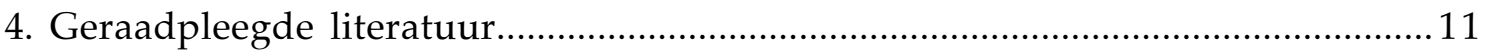

Bijlage 


\section{Inleiding}

In het IVM dat nu wordt ontwikkeld, staat het verloop van verschillende belangrijke ziekteprocessen en daarvan op een adequaat aggregatieniveau afgeleide patiëntenstromen centraal. De uitkomsten van het IVM worden gegenereerd als gevolg van al dan niet in de toekomst gewijzigde patiëntenstromen. De vragen die hierbij met behulp van het IVM kunnen worden geanalyseerd, richten zich op activiteiten die voortkomen uit het beleid op nationaal niveau, een en ander tegen de achtergrond van demografische, epidemiologische, medisch-technologische en socio-culturele ontwikkelingen.

Het definitierapport Volksgezondheid ToekomstVerkenning-1997 (1995) laat zien dat VTV'97 dit beleid 'behulpzaam' wil zijn met het geven van een overzicht en analyse van gegevens. Het is binnen dit kader waar de vraagstellingen voor het IVM kunnen worden geplaatst. Deze vraagstellingen worden in het definitierapport gepresenteerd in de vorm van de onderstaande zeven thema's:

1. Geactualiseerde beschrijving van de gezondheidstoestand en de determinanten die bepalend zijn voor de gezondheidstoestand

2. Gezondheidsverschillen en de gezondheidstoestand van specifieke groepen in de Nederlandse bevolking

3. Ernst/impact van ziekten in relatie tot geïntegreerde gezondheidsmaten

4. Effecten van preventie

5. Effecten van zorg

6. Gevolgen van ziekten voor het zorggebruik en de zorgbehoefte

7. Toekomstige ontwikkelingen in de gezondheidstoestand (van delen) van de bevolking, de determinanten ervan en de gevolgen voor de gezondheidszorg.

Bron: Definitierapport VTV (1995)

Voor de beantwoording van dit type vraagstellingen is het noodzakelijk dat het IVM wordt gevuld met daartoe terzake dienende gegevens. In schema 1 volgt een overzicht van mogelijke data die voor het IVM kunnen worden verzameld.

Dit rapport betreft het onderzoek naar een algemeen methodologische aanpak (oftewel een generieke aanpak) voor de raming van de kosten van medische behandelingen en zorggebruik (punten 3 en 4 van schema 1). Het produkt van de generieke aanpak wordt aangeduid als het generieke raamwerk.

De nadruk in IVM ligt meer op het krijgen van inzicht in de mogelijke toekomstige ontwikkelingen in zorg en kosten. Als zodanig moet het generieke raamwerk worden gezien als het onderliggende framework voor het computerprogramma in IVM.

De onderliggende modellen van het generieke raamwerk zijn in de Bijlage bij het rapport opgenomen. 


\section{Schema 1: Benodigde Data IVM}
Algemeen:
per ziektecategorie naar leeftijd en geslacht

1. kosten preventieve interventies

2. kosten therapeutische interventies (zie ook punt $\mathbf{1 2}$ met betrekking tot besparingen in behandelingskosten)

3. kosten medische behandelingen

4. zorggebruik

5. verdeling (gezonde) bevolking over risicofactoren (onafhankelijk/afhankelijk)

6. verdeling zieke bevolking naar ernst ziektestadium

7. verdeling incidenties (opnames) over medische behandelingen

8. overgangskansen vanuit Gezond en vanuit Ziek

9. omvang Prevalente Bevolking

10. effecten van medische behandeling (Zorggebruik) met betrekking tot het verdere ziekteverloop, het zorggebruik, de levensverwachting en kwaliteit van leven

11. effecten van preventieve interventies met betrekking tot risicoprofiel, incidenties, en zorggebruik

12. effecten van therapeutische interventies met betrekking tot het verdere ziekteverloop, de levensverwachting, kwaliteit van leven, en de bestaande zorgvraag. 


\section{Uitgangspunten}

De algemene opbouw van een generiek raamwerk voor zorg en kosten heeft plaatsgevonden volgens de onderstaande uitgangspunten:

1. De patiëntenstromen moeten zich bevinden op een voldoende geaggregeerd niveau van het ziekteproces.

2. De generieke aanpak is zodanig dat de benodigde data op een geautomatiseerde manier kunnen worden aangeleverd.

3. Het zorggebruik en de kosten moeten zich voldoende kunnen discrimineren in de verschillende stadia van het ziekteproces.

4. Het generieke raamwerk moet passen binnen de geïntegreerde structuur van IVM.

5. Het raamwerk moet aanknopingspunten bieden voor interventies waarmee de kosten en gezondheidseffecten van toekomstige trajecten (scenario's) kunnen worden gegenereerd.

Uitgangspunt 1 hangt samen met de doelstellingen en eisen die aan het model worden gesteld. Deze doelstellingen en eisen worden afgeleid van de beleidsopties die met behulp van het model worden geanalyseerd. Dit uitgangspunt vindt zijn weerslag in de behandeling van de algemene opbouw IVM (figuur 1) en het prevalentieschema IVM (figuur 2).

Het belang van uitgangspunt 2 komt ter sprake in het tweede gedeelte van het rapport. Waar het bij dit uitgangspunt om gaat is dat het juiste aggregatieniveau van gegevensverzameling wordt gekozen. Uit het tweede gedeelte blijkt dat de toepassing van de generieke aanpak op $\mathrm{CHZ}$ niet goed mogelijk was geweest zonder de beschikbaarheid van het geautomatiseerde gegevensbestand van de Stichting Informatiecentrum (SIG).

Uitgangspunt 3 refereert aan het probleem dat de verschillende ziektecategorieën hun eigen specifieke behandelingspatronen en ziektestadia kennen. Dit betekent enerzijds dat de behandelingspatronen en ziektestadia ziektespecifiek herkenbaar moeten zijn, en anderzijds dat deze zich niet mogen verliezen in details, maar wel zodanig gegroepeerd moeten zijn dat er nog kostprijzen aan het zorggebruik kunnen worden verbonden. Dit uitgangspunt is verwerkt in de figuren 1 (ziektemodel van IVM) en 2 (zorgmodellen) van de Bijlage bij het rapport.

Uitgangspunt 4 is tweeledig:

a) de overgang van patiënten van de ene ziekte naar de andere ziekte dan wel van het ene ziektestadium naar het andere ziektestadium. Deze overgangen vinden hun weerslag in het prevalentieschema (figuur 2);

b) geen selectie van doelgroepen naar patiëntkenmerken, op basis waarvan medische behandelingen kunnen worden geïndiceerd. De patiëntenstromen doorlopen daardoor geen specifieke behandelingspatronen. Dit aspect wordt behandeld bij het onderdeel 'kosten' in het tweede gedeelte van het rapport.

Uitgangspunt 5 moet zich nog 'bewijzen' aan de hand van de resultaten die door middel van het computerprogramma worden doorgerekend.

De vraagstelling van het onderzoek luidt dan op welke manier zorg aan kosten kan worden gekoppeld waarin bovenstaande uitgangspunten zijn verwerkt, en wat nu zo generiek is aan de voorgestelde aanpak. Het generieke van de voorgestelde aanpak kan het beste worden voorgesteld in de vorm van een vijf-stappen-plan:

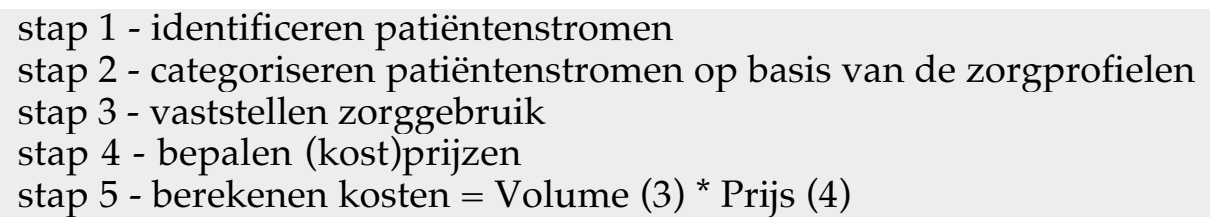

De bedoeling is dat op deze manier de generieke aanpak algemeen toepasbaar is voor de ziektecategorieën die in IVM zijn (of worden) opgenomen. 


\section{Algemene opbouw}

Het doel van het IVM kan worden omschreven als het ontwikkelen en analyseren van scenario's over mogelijke toekomstige ontwikkelingen van incidenties, prevalenties, zorgbehoefte en kosten van verschillende ziektecategorieën in de Nederlandse bevolking.

In figuur 1 is de algemene opbouw van het IVM opgenomen, zoals door ons geïnterpreteerd.

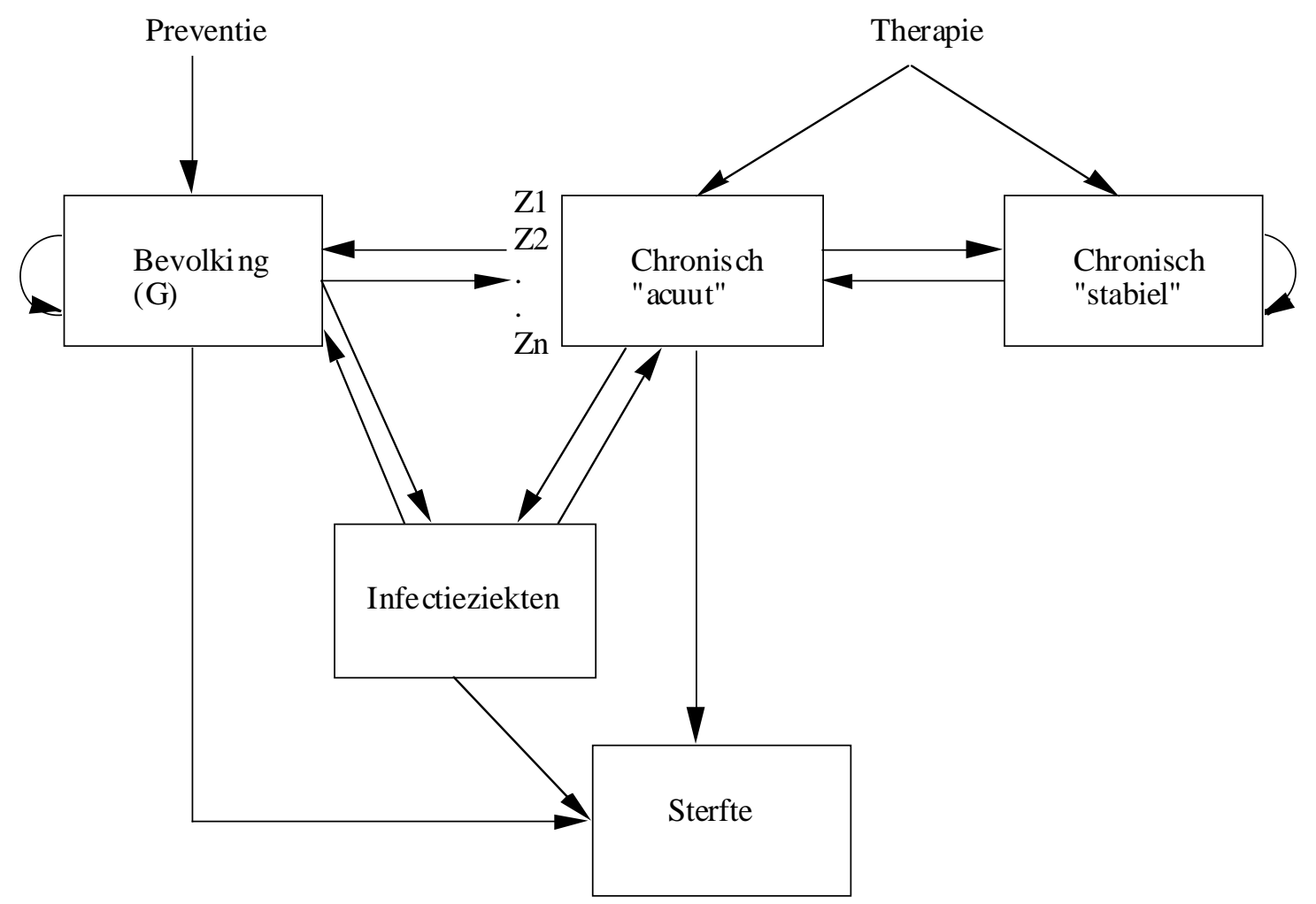

Figuur 1: Algemene opbouw IVM, naar eigen ontwerp

In deze figuur is doelbewust een onderscheid gemaakt tussen de acute fase en de stabiele fase van de verschillende stadia van een chronische ziekte. Hiervoor zijn twee redenen:

- de twee fases verschillen in tijdsduur van elkaar. Modelmatig gezien omvat de tijdsduur van de acute fase een periode van een jaar, terwijl de tijdsduur van de stabiele fase de periode bestrijkt totdat een nieuwe gebeurtenis optreedt.

- de twee fases verschillen qua zorgintensiteit en kosten. De zorgintensiteit en de daarmee samenhangende kosten zijn ziektespecifiek. Bij de 'lethal diseases' zoals CHZ worden de meeste kosten gemaakt in de acute fase van het ziektestadium.

Het is vooral om het laatste argument dat we de algemene opbouw van het IVM volgens onze eigen interpretatie hier hebben opgevoerd. In essentie wijkt deze interpretatie overigens niet af van de wijze waarop IVM wordt gemodelleerd (vgl. Van Genugten e.a., 1994; Vrijsen, 1993; en privé-communicatie Van Genugten, 1995). 
De infectieziekten nemen door hun specifieke karakter een aparte plaats in het IVM in. De tijdsduur omvat veelal een periode van een aantal dagen, reden waarom infectieziekten in dit rapport verder buiten beschouwing worden gelaten. (N.B. Een bijzondere infectieziekte als AIDS heeft een semi-chronisch karakter.)

Op 1 januari van elk jaar loopt iedere persoon in het IVM de kans getroffen te worden door een acute aandoening van een chronische ziekte. In figuur 2 worden de toestandsovergangen of gebeurtenissen weergegeven die op dat tijdstip in het IVM kunnen plaatsvinden.

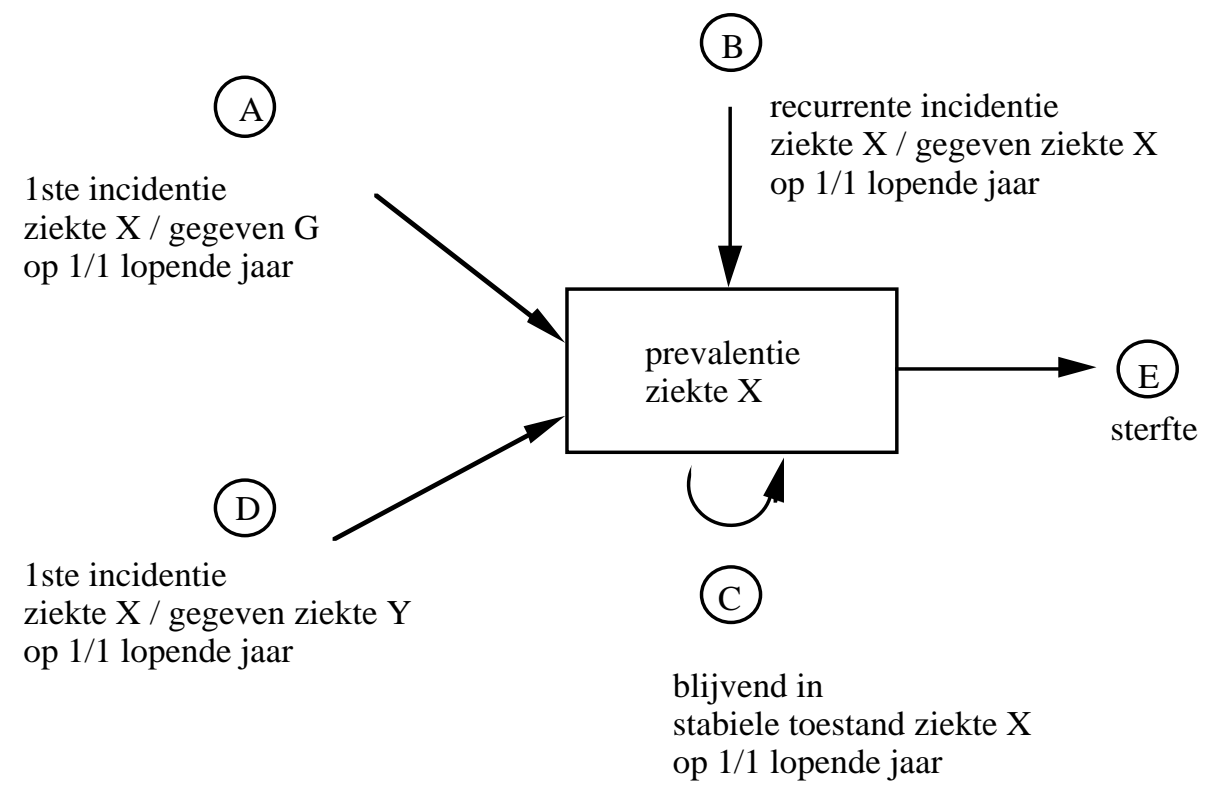

Figuur 2: Prevalentieschema IVM, naar eigen ontwerp

Er is een aantal redenen om in figuur 2 het onderscheid te maken tussen de verschillende gebeurtenissen (A t/m E). Deze redenen betreffen de verschillen in prognose, invaliditeit, en behandeling (of zorgintensiteit). Wanneer we het verschil toespitsen op zorgintensiteit, ontstaat het volgende beeld:

A initiële incidentie op $1 / 1$ van het lopende jaar met ziekte $X$ als hoofddiagnose vanuit de gezonde bevolking (zijnde personen zonder ziekte $\mathrm{X}$ ). De medische behandelingen kunnen bestaan uit de behandelingen vóór en/of tijdens opname in ziekenhuis, de behandeling in verpleeghuis en de follow-up-behandelingen na ontslag uit het ziekenhuis.

B recurrente incidentie op 1/1 van het lopende jaar met dezelfde ziekte $X$ als hoofddiagnose vanuit de zogenaamde zieke bevolking (zijnde personen in een stabiele fase van ziekte X). Bij de meeste chronische ziekten wordt niet gesproken van recurrentie wanneer er sprake is van een vererging van de ziekte, maar alleen van heropname. In dat geval zijn recurrentie en heropname voor het model synoniem aan elkaar. De medische behandelingen zijn dezelfde als die genoemd onder $\mathrm{A}$, maar zijn vaak intensiever.

C de groep patiënten op 1/1 van het lopende jaar waarvan de gezondheidstoestand met betrekking tot ziekte X stabiel blijft. De medische behandeling bestaat uit follow-up-behandelingen waarvan de zorgintensiteit ziektespecifiek is.

$\mathrm{D}$ initiële incidentie op 1/1 van het lopende jaar met ziekte $X$ als hoofddiagnose bij de aanwezigheid van een andere ziekte $Y$ als nevendiagnose. De medische behandelingen zijn intensiever dan die genoemd onder A. 
De recurrente incidentie genoemd onder $B$ betreft een gebeurtenis op een tijdstip één of meer jaren na het moment waarop de initiële incidentie van dezelfde ziekte als hoofddiagnose plaatsvond. Mogelijk verwarrend is dat er ook sprake is van recurrente incidentie wanneer deze zich voordoet in hetzelfde jaar dat de eerste manifestatie met dezelfde ziekte als hoofddiagnose zich heeft voorgedaan. De notatie B wordt daarom uitgebreid met de notaties B2 voor recurrente incidenties op 1/1 van het lopende jaar respectievelijk B1 voor recurrente incidenties op $1 / 7$ van het lopende jaar. Het midden van het jaar is gekozen omdat we ervan uitgaan dat het gemiddeld een half jaar duurt voordat na 1/1 van het lopende jaar een nieuwe recurrentie optreedt.

We hebben met betrekking tot de Algemene Opbouw IVM (figuur 1) en het Prevalentieschema (figuur 2) een aantal keuzen gemaakt. Deze keuzen onderscheiden zich als volgt:
a) een acute en stabiele fase van het ziekteproces;
b) de recurrente fase in het lopende jaar van het ziekteproces B1;
c) de drie verschillende patiëntenstromen, aangeduid als

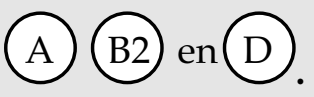

De facetten van deze keuzen vormen de bouwstenen van het ziektemodel van IVM, dat is opgenomen in de Bijlage bij het rapport.

Het generieke raamwerk zorg en kosten is gebaseerd op het ziektemodel van IVM. We laten het generieke raamwerk representeren door het patiëntenstroomschema van IVM dat in figuur 3 is weergegeven. 


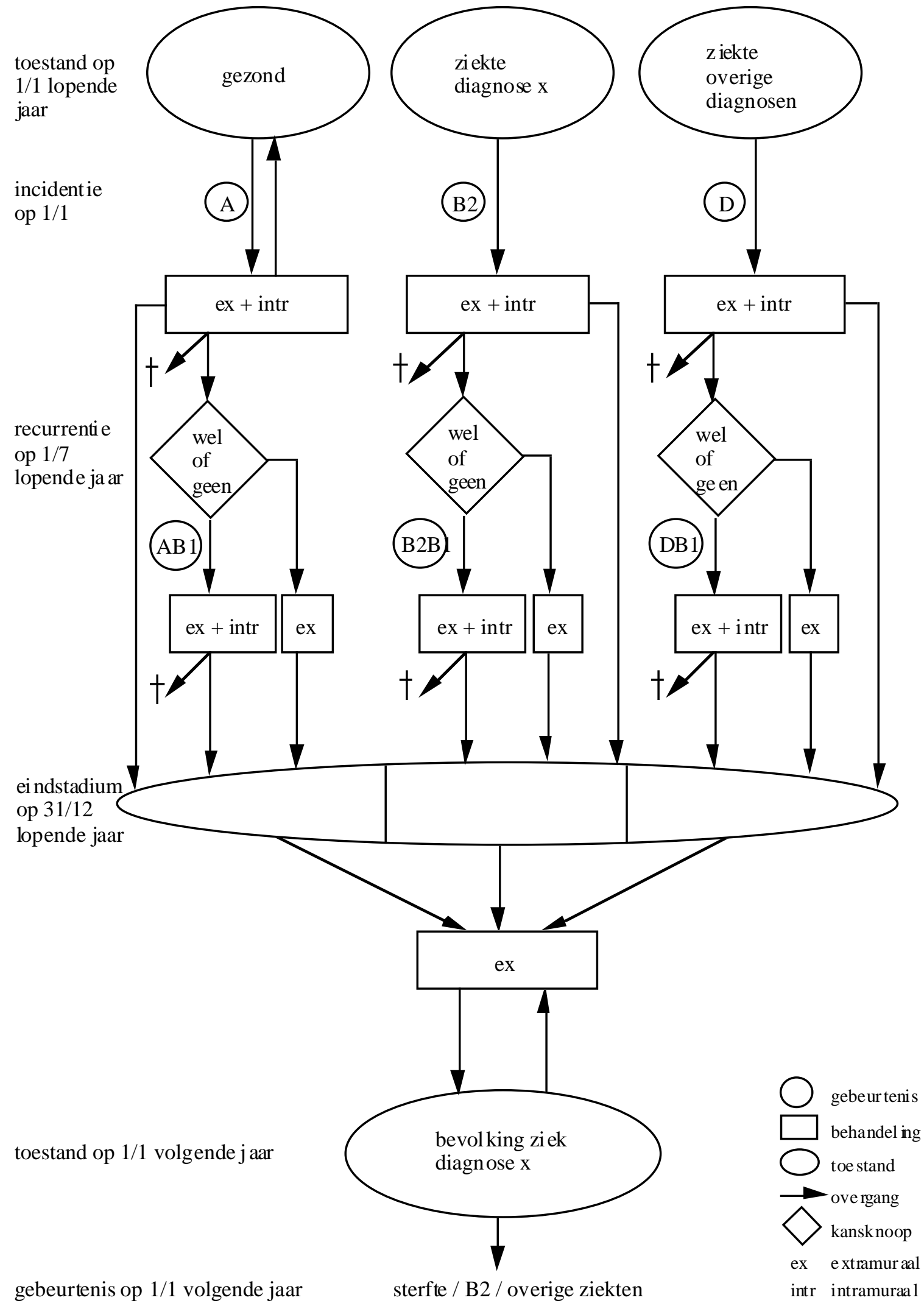

Figuur 3: Patiëntenstroomschema IVM, naar eigen ontwerp 
Het patiëntenstroomschema van IVM geeft informatie die van belang is om te bepalen hoeveel personen van een bepaalde type zorg gebruik maken en op welk moment in het ziekteproces de specifieke zorgvraag zich voordoet. Het in het patiëntenstroomschema onderliggende zorgmodel is in de Bijlage opgenomen.

Samenvattend is de essentie van het generieke raamwerk tweeledig:

1. de verschillende stadia van het ziekteproces kunnen op geaggregeerd niveau worden onderscheiden in verschillende typen patiëntenstromen.

2. het verschil in zorggebruik en het daaraan gekoppelde kostenpatroon die door de verschillende patiëntenstromen worden gegenereerd, kan op geaggregeerd niveau zichtbaar worden gemaakt.

\section{Geraadpleegde literatuur}

Boas, G.M. Scenario-analyse Economische Aspecten Coronaire Hartziekten (proefschrift). Maastricht: Rijksuniversiteit Limburg, 1994.

CBS (Centraal Bureau voor de Statistiek). Sterfte naar doodsoorzaak. Maandbericht Gezondheid 1994/9, vol.13.

Hartunian, N.S., Smart, C.N. and Thompson, M.S. The incidence and economic costs of major health impairments. A comparative analysis of cancer, motor vehicles injuries, coronary heart disease and stroke. Lexington Mass (Toronto): Lexington Books, 1981.

Koopmanschap, M.A., Roijen, L. van, Bonneux, L. Kosten van ziekten in Nederland. MGZ, nr. 91-03, 1991.

Ruwaard, D., Berg Jeths, A. van den, Janssen J. e a., Definitie voor de opzet van de studie Volksgezondheid Toekomst Verkenning 1997. RIVM, 1995 no. 431501013..

SIG (Stichting Informatiecentrum Gezondheidszorg). Documentatie met betrekking tot 1993. SIG-zorginformatie 1995.

Van Genugten, M.L.L., De Bruin, A.J. e.a. Integrale volksgezondheid modellering (IVM): structuur en omgeving. RIVM, interne notitie, 1994, p. 10.

Vrieze O.J., Boas G.M., Janssen, J.H.A.. Een simulatiemodel voor Toekomst Analyse van Coronaire Hartziekten. Utrecht: Jan van Arkel, 1994.

Vrijsen, W. Implementatie Structuur IVM. RIVM, interne notitie, bijlage A, p. 12. 


\title{
Deel II
}

\section{Generiek Raamwerk}

\author{
Zorg en Kosten
}

toegepast op

\section{Coronaire HartZiekten}

\author{
In opdracht van het \\ Centrum voor VolksgezondheidsToekomstVerkenningen, \\ RIVM
}

Project Integrale Volksgezondheidsmodellering 
Generiek Raamwerk Zorg en Kosten 
Generiek Raamwerk Zorg en Kosten

\section{Inhoudsopgave}

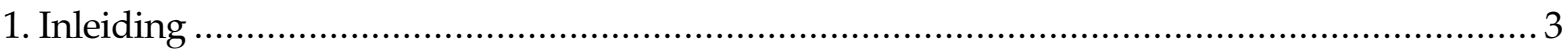

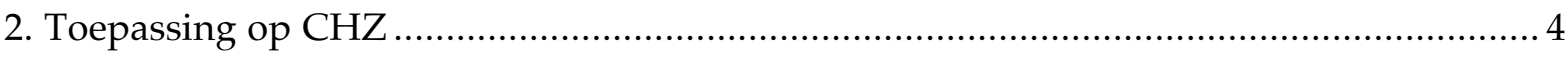

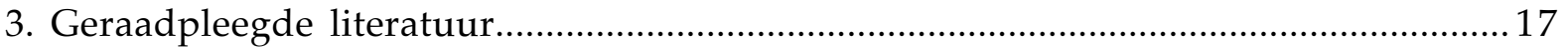

Bijlage 


\section{Inleiding}

Dit rapport betreft de toepassing van de in deel I omschreven generieke aanpak zorg en kosten met betrekking tot $\mathrm{CHZ}$. De toepassing van de generieke aanpak heeft het karakter van een pilot-studie. Er is naar gestreefd deze toepassing zo goed mogelijk te operationaliseren met data. Hiervoor is gebruik gemaakt van diverse gegevensbronnen die in de Bijlage bij dit rapport worden toegelicht. Deze gegevens worden in IVM gebruikt om met behulp van een computerprogramma op een geautomatiseerde wijze te komen tot een gevuld schema voor patiëntenstromen en de daaraan gekoppelde zorg en kosten. Conform deze aanpak kunnen met IVM analyses worden verricht over mogelijke ontwikkelingen met betrekking tot sterfte, zorg en kosten in toekomstige perioden. De resultaten van zo'n exercitie zijn niet in dit rapport opgenomen, maar zullen separaat worden gepresenteerd.

Het rapport heeft een aparte bijlage. 


\section{Toepassing op $\mathrm{CHZ}$}

In deze sectie wordt de toepassing van de generieke aanpak gedemonstreerd. We bedoelen met de generieke aanpak dat het zorggebruik en de bijbehorende kostprijzen in het IVM worden gekoppeld aan patiëntenstromen.

De toepassing is om twee redenen beperkt tot het terrein van de $\mathrm{CHZ}$ :

a. De aanwezige kennis over CHZ. Hiervoor zijn twee redenen: 1) het centrum Volksgezondheid Toekomstverkenningen (VTV) heeft als resultaat van de samenwerking van het RIVM met het instituut Maatschappelijke Gezondheidszorg (iMG) van de Erasmus Universiteit Rotterdam (EUR) een op de EUR-kennis gebaseerde voorlopige versie van een CHZ-model in IVM geïmplementeerd (Bonneux e.a., 1994). 2) MERIT heeft de kennis ingebracht die is verkregen met het CHZ-scenario-onderzoek dat in opdracht van de Stuurgroep Toekomstscenario's Gezondheidszorg (STG) door de Rijksuniversiteit Limburg is uitgevoerd (Vrieze e.a., 1995).

b. De benodigde data over zorggebruik. De generieke aanpak brengt met zich mee dat de benodigde data volgens dezelfde methodiek moeten worden verzameld en aangeleverd. Het centrum VTV heeft met betrekking tot de gegevens over het zorggebruik in het ziekenhuis een aanvraag bij de Stichting Informatiecentrum Gezondheidszorg (SIG) ingediend. De SIG-aanvraag is beperkt tot CHZ omdat de toepassing van de generieke aanpak nog in de pilot-fase verkeert. Een toelichting op deze SIG-aanvraag en de aangeleverde data is opgenomen in bijlage I van de Bijlage bij dit rapport. De verantwoording voor de gebruikte data is weergegeven in bijlage II van de Bijlage.

Er zijn in Nederland weinig gegevens bekend over de kosten die voor de verschillende ziektecategorieën in het IVM worden gemaakt. Het enige (globale) vergelijkingsmateriaal waarmee een kostenvalidering van het model kan worden uitgevoerd is de publikatie van Koopmanschap e.a. (1991). Het Financieel Overzicht Zorg (FOZ) uit 1990 heeft als basis voor hun berekeningen gediend. Vervolgens zijn deze kosten volgens bepaalde verdeelsleutels toegerekend aan de ziektecategorieën. De verdeelsleutel die is gehanteerd betreft de hoeveelheid zorg die voor een bepaalde ziektecategorie in een zorgsector wordt aangewend. Er zijn door Koopmanschap e.a. 18 zorgsectoren gedefinieerd.

Kosten vormen het produkt van volume (aantal) en (kost)prijs. Een kostprijsbepaling vereist dat een verrichtingenprofiel van de desbetreffende behandelingen wordt opgesteld. Het probleem bij deze benadering is tweeledig:

1. er zullen altijd gevallen zijn waarin de benodigde gegevens met betrekking tot een kostprijsbepaling ontbreken en dat het tijd en inzet kost om deze te verzamelen.

2. het IVM is als integraal model niet gedetailleerd genoeg gemodelleerd om 'op eigen kracht' de kosten door middel van de vermenigvuldiging van het aantal behandelingen met de kostprijzen zodanig door te rekenen, dat daarmee de totale kosten van de desbetreffende ziektecategorie op een voldoende betrouwbare manier kunnen worden weergegeven. De reden hiervoor is dat in IVM geen patiëntenstromen worden onderscheiden die specifieke behandelingsprofielen doorlopen (de zogenaamde bottom-up-methode).

Bij de kostenbenadering die in dit onderzoek is gevolgd zijn we uitgegaan van de totale kosten zoals die volgens Koopmanschap e.a. (1991) zijn weergegeven.

Deze kostenbenadering houdt in dat de totale kosten per zorgsector van de desbetreffende ziektecategorie zijn herleid tot kostprijzen. Deze herleiding hebben we simpelweg verricht door de kosten te delen door een bepaalde volume-indicator. 
De gebruikte volume-indicatoren zijn:

$\begin{array}{lll}\text { ziekenhuis } & - & \text { opnames } \\ \text { huisarts } & - & \text { consulten } \\ \text { specialist } & - & \text { 1) consulten } \\ & & \text { 2) poliklinische diagnostiek } \\ \text { verpleeghuis } & - & \text { opnames } \\ \text { kruiswerk } & - & \text { consulten }\end{array}$

Een toelichting op de kostprijsberekening is opgenomen in bijlage III van de Bijlage bij dit rapport.

We hebben de toepassing van de generieke aanpak gedemonstreerd aan de hand van een ingevuld patiëntenstroomschema (figuren $1 \mathrm{t} / \mathrm{m} 3$ ) en een ingevuld zorgmodel (figuren $4 \mathrm{t} / \mathrm{m} \mathrm{9}$ ).

In bijlagen II en III van de Bijlage zijn de overzichten zorgprofiel ziekenhuis en morbiditeit respectievelijk kostprijzen opgenomen. 
Generiek Raamwerk Zorg en Kosten

\section{A. Patiëntenstroomschema IVM/CHZ}

Figuur 1: $\quad$ Patiëntenstroomschema IVM/CHZ (M)

Figuur 2: $\quad$ Patiëntenstroomschema IVM/CHZ (V)

Figuur 3: $\quad$ Patiëntenstroomschema IVM/CHZ $(\mathrm{M}+\mathrm{V})$ 
Generiek Raamwerk Zorg en Kosten

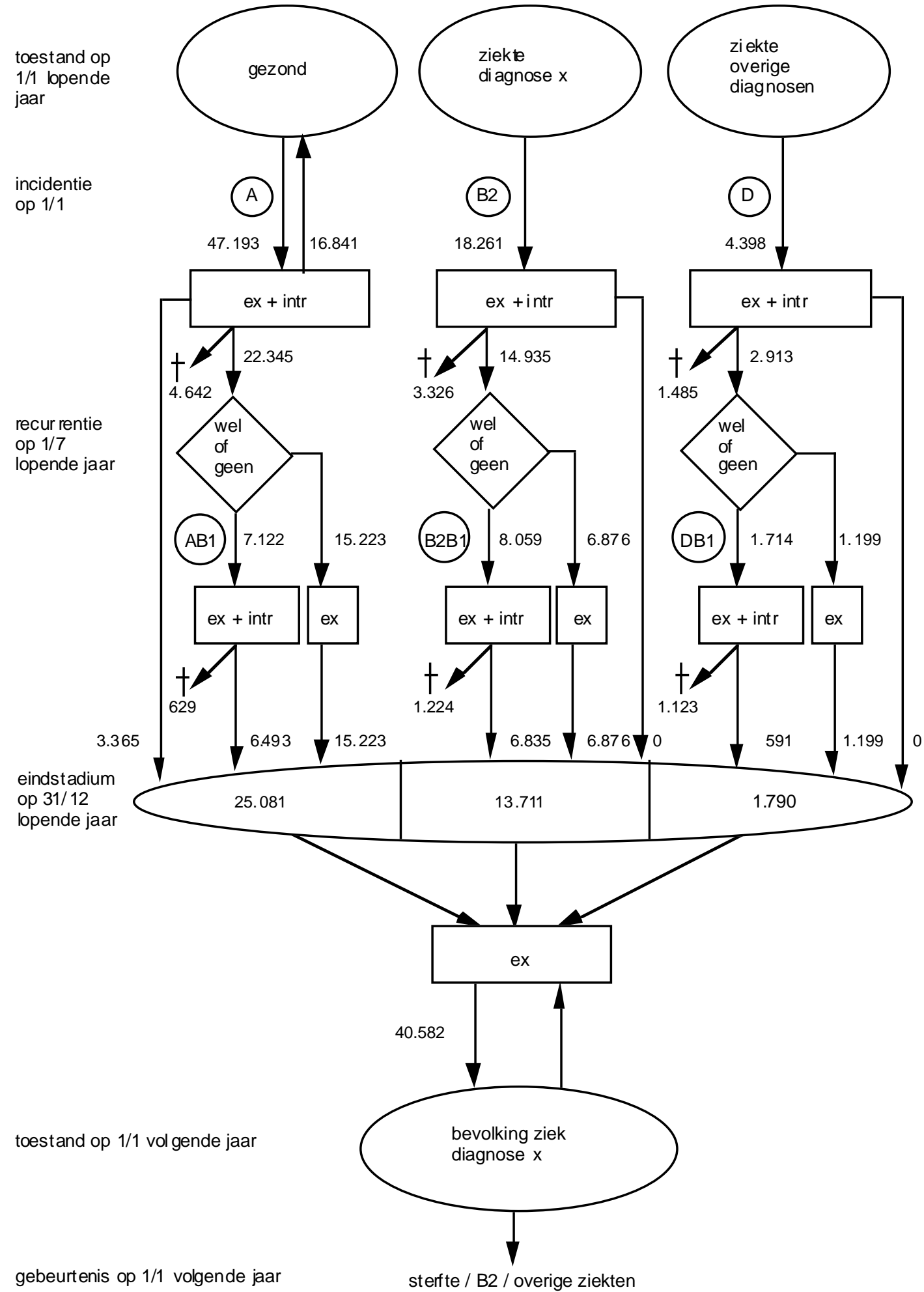

Figuur 1: Patiëntenstroomschema IVM/CHZ (M) 
Generiek Raamwerk Zorg en Kosten

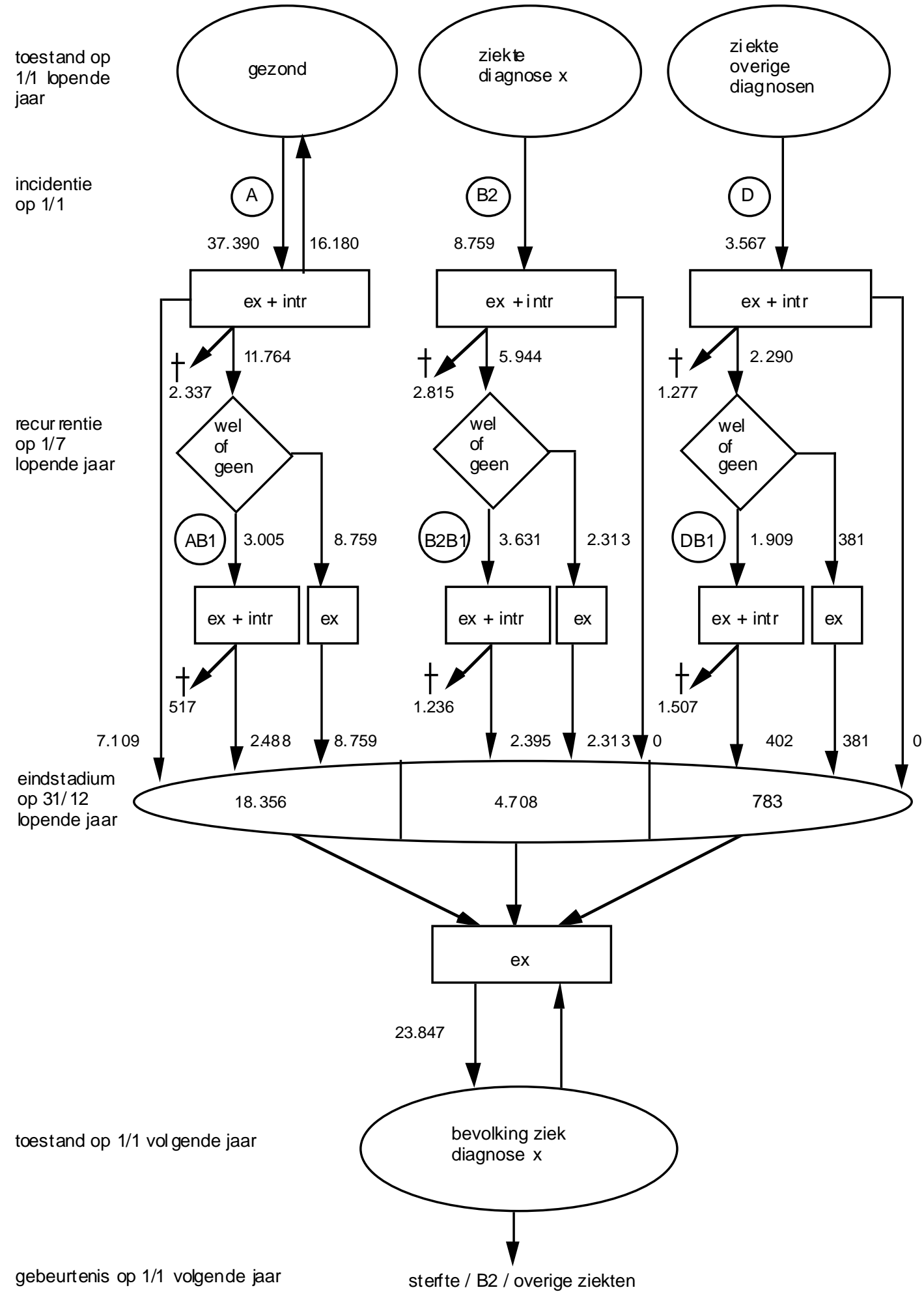

Figuur 2: Patiëntenstroomschema IVM/CHZ (V) 
Generiek Raamwerk Zorg en Kosten

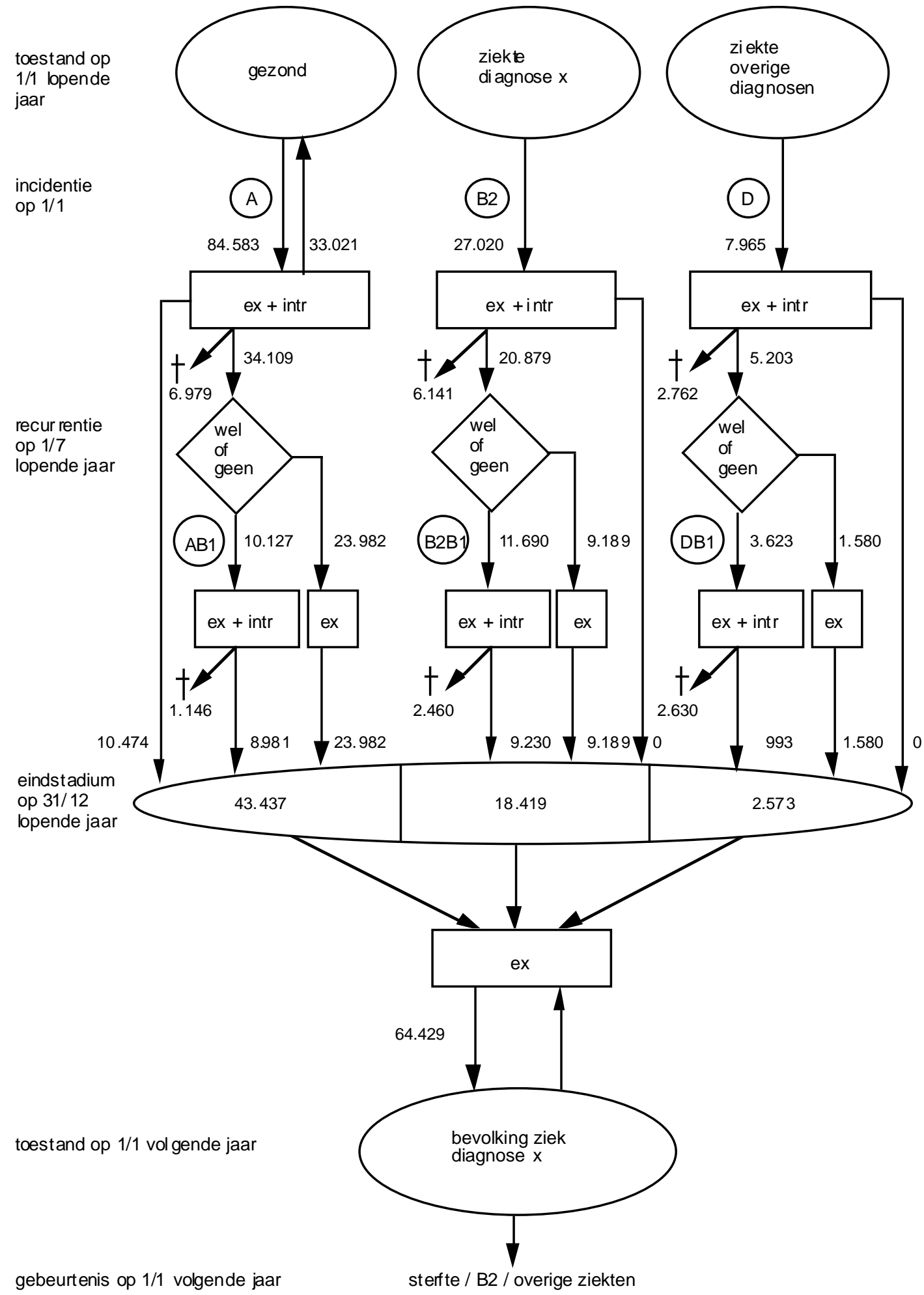

Figuur 3: Patiëntenstroomschema IVM/CHZ $(M+V)$ 
Generiek Raamwerk Zorg en Kosten

B. Zorgmodel IVM/CHZ

Figuur 4: $\quad$ Zorgmodel IVM/CHZ/ A (M)

Figuur 5: $\quad$ Zorgmodel IVM/CHZ/B2 (M)

Figuur 6: $\quad$ Zorgmodel IVM/CHZ/D (M)

Figuur 7: $\quad$ Zorgmodel IVM/CHZ/ A (V)

Figuur 8: $\quad$ Zorgmodel IVM/CHZ/B2 (V)

Figuur 9: $\quad$ Zorgmodel IVM/CHZ/D (V) 


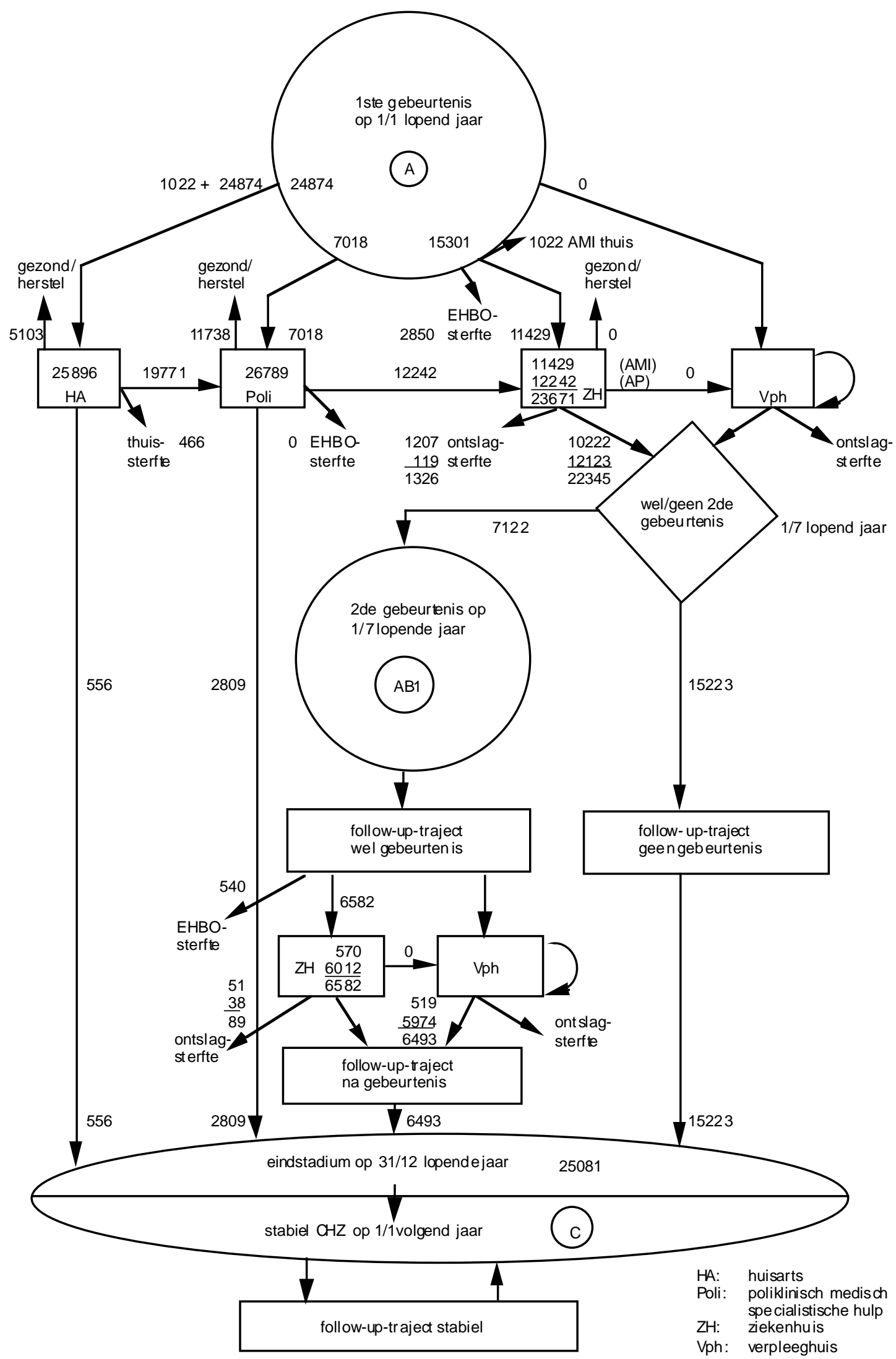

Figuur 4: Zorgmodel IVM/CHZ/A (M) 


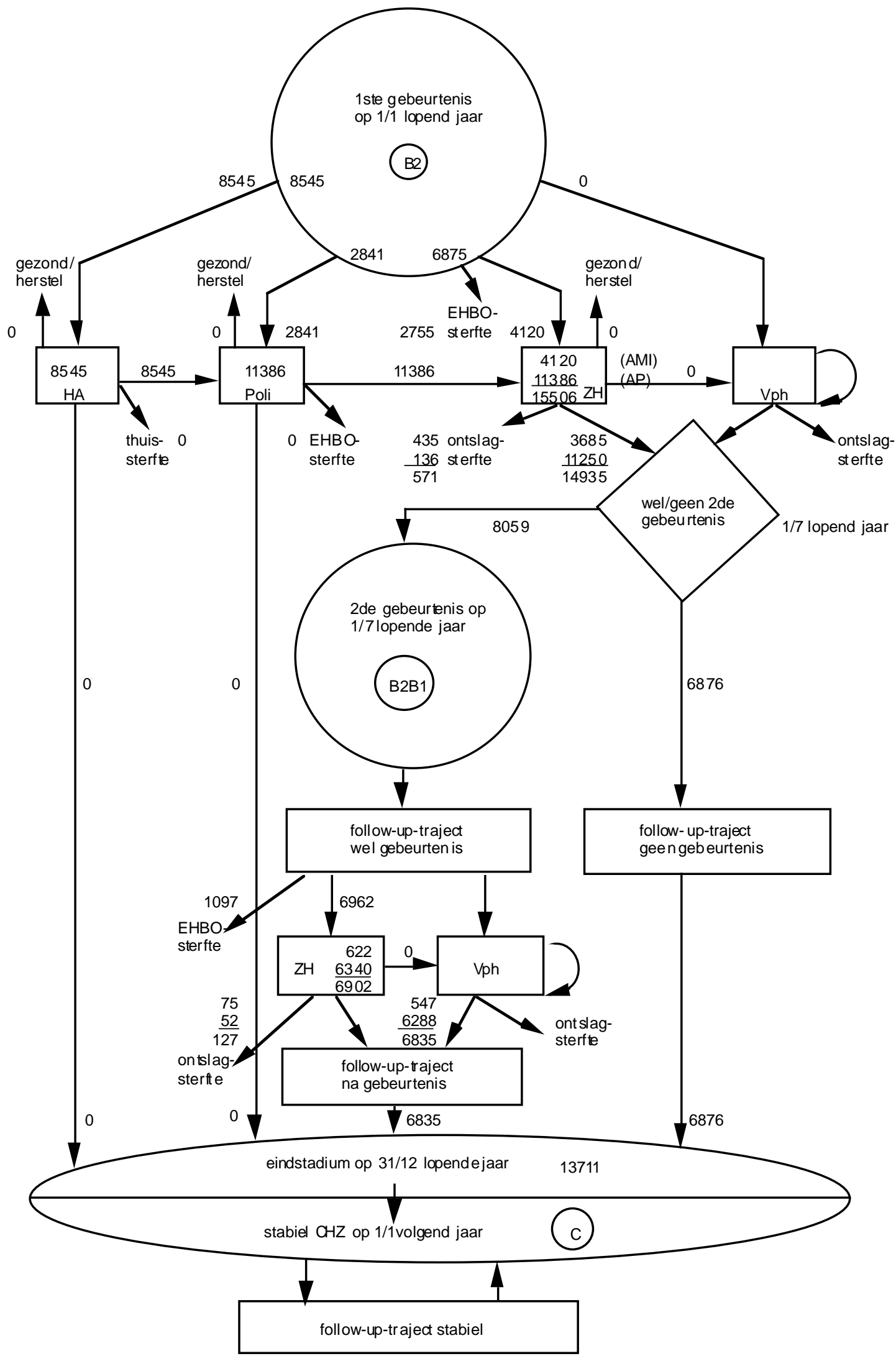

Figuur 5: Zorgmodel IVM/CHZ/B2 (M) 
Generiek Raamwerk Zorg en Kosten

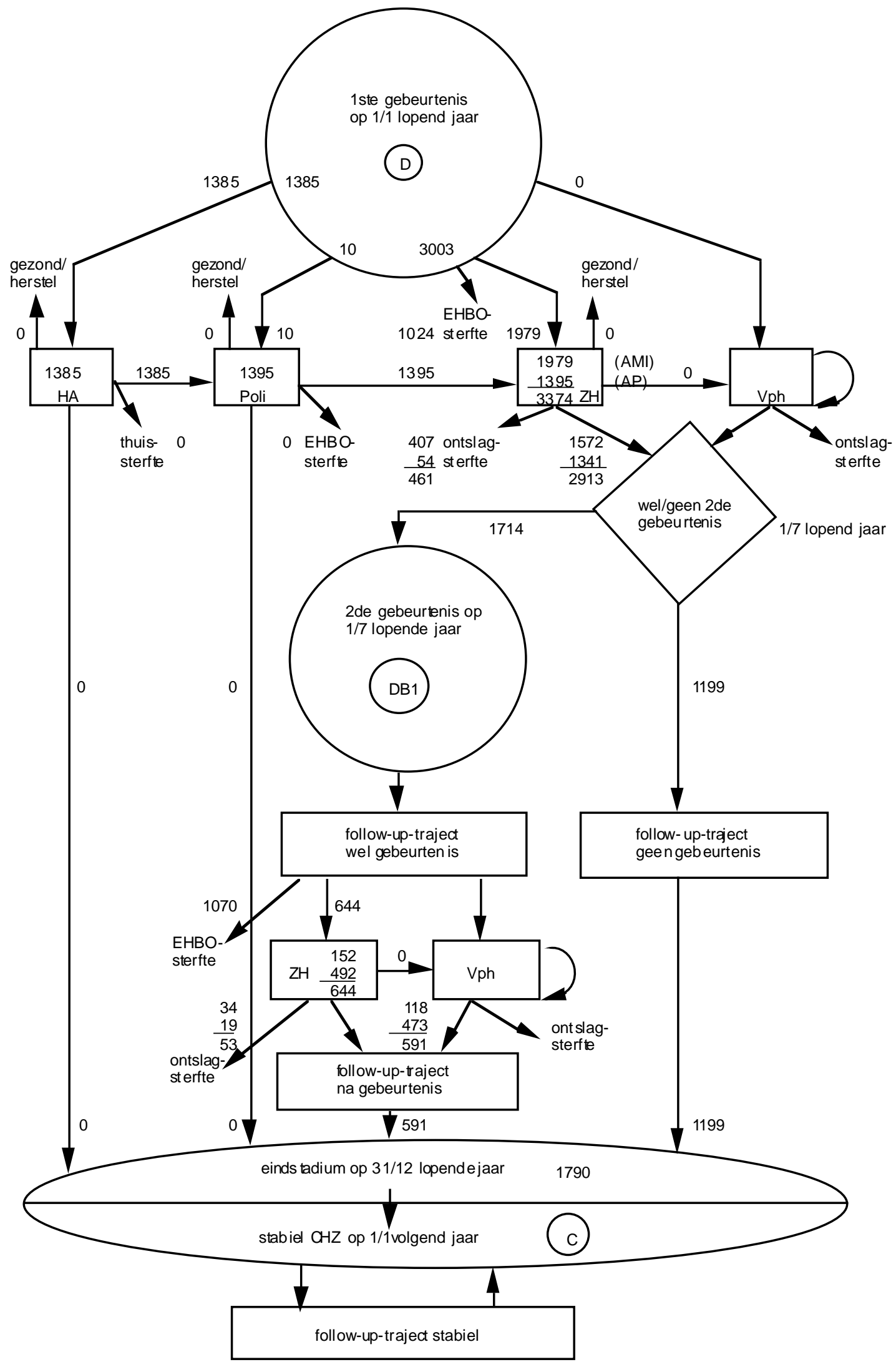

Figuur 6: Zorgmodel IVM/CHZ/D (M) 


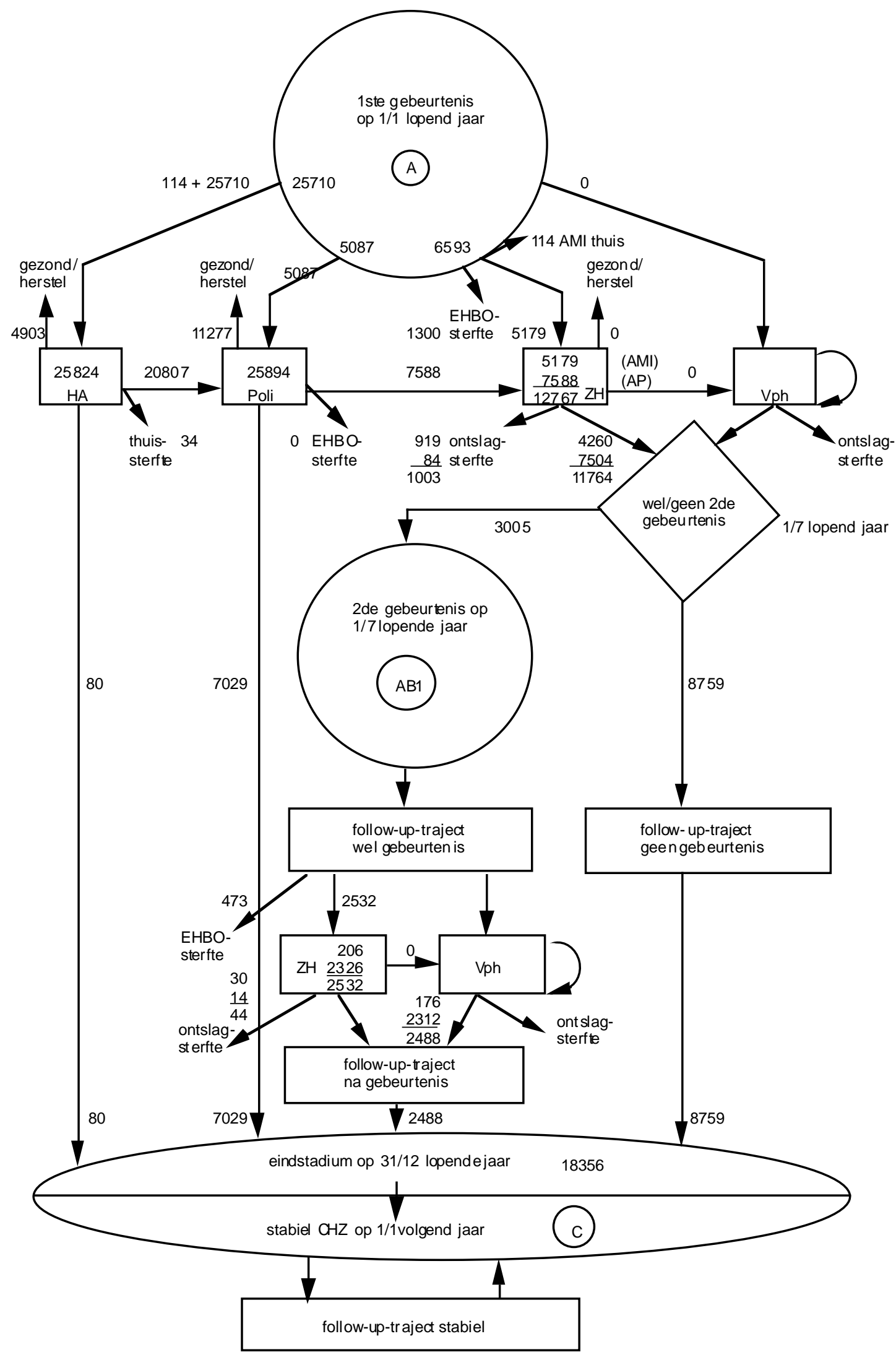

Figuur 7: Zorgmodel IVM/CHZ/A (V) 
Generiek Raamwerk Zorg en Kosten

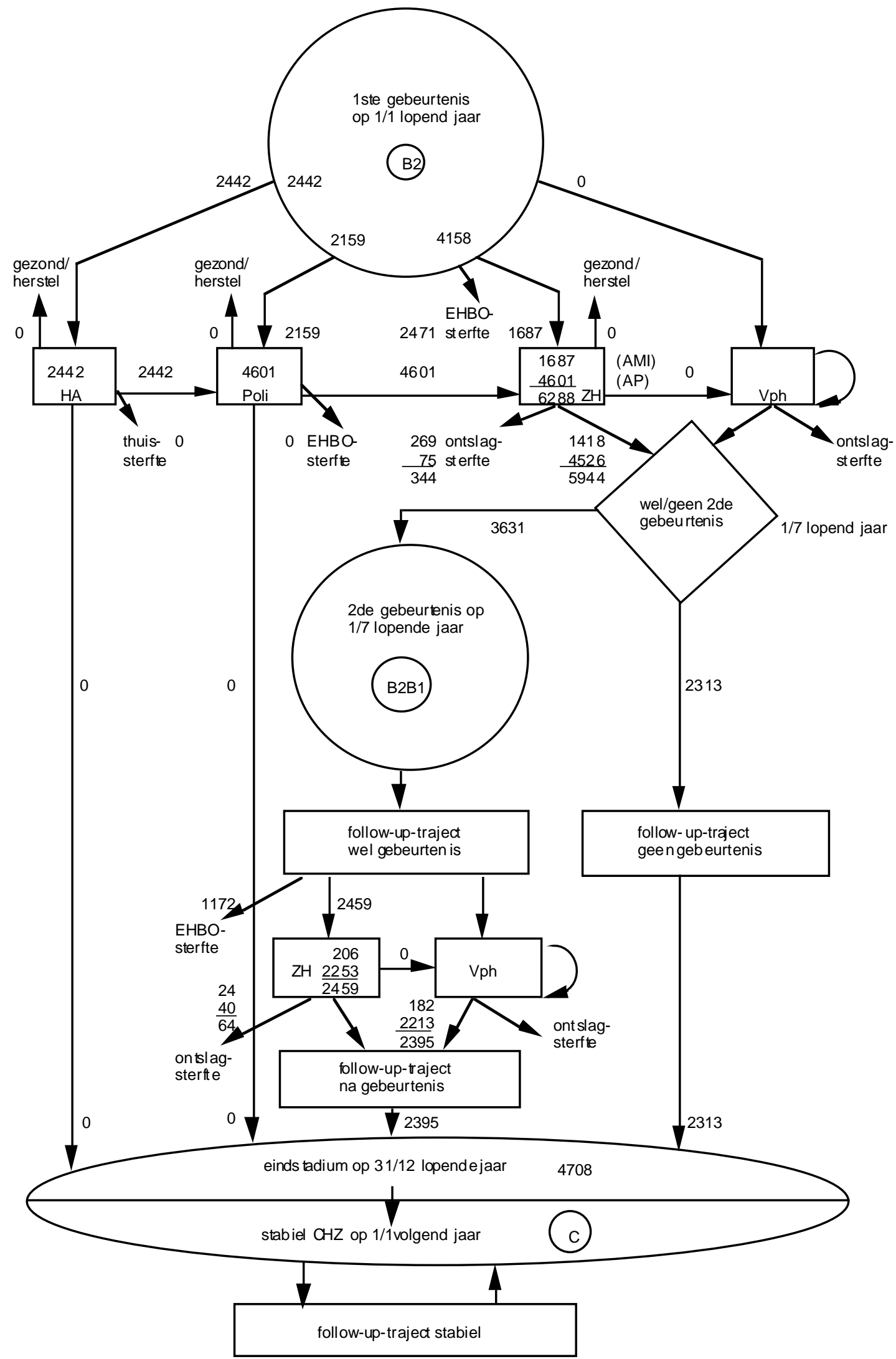

Figuur 8: Zorgmodel IVM/CHZ/B2 (V) 


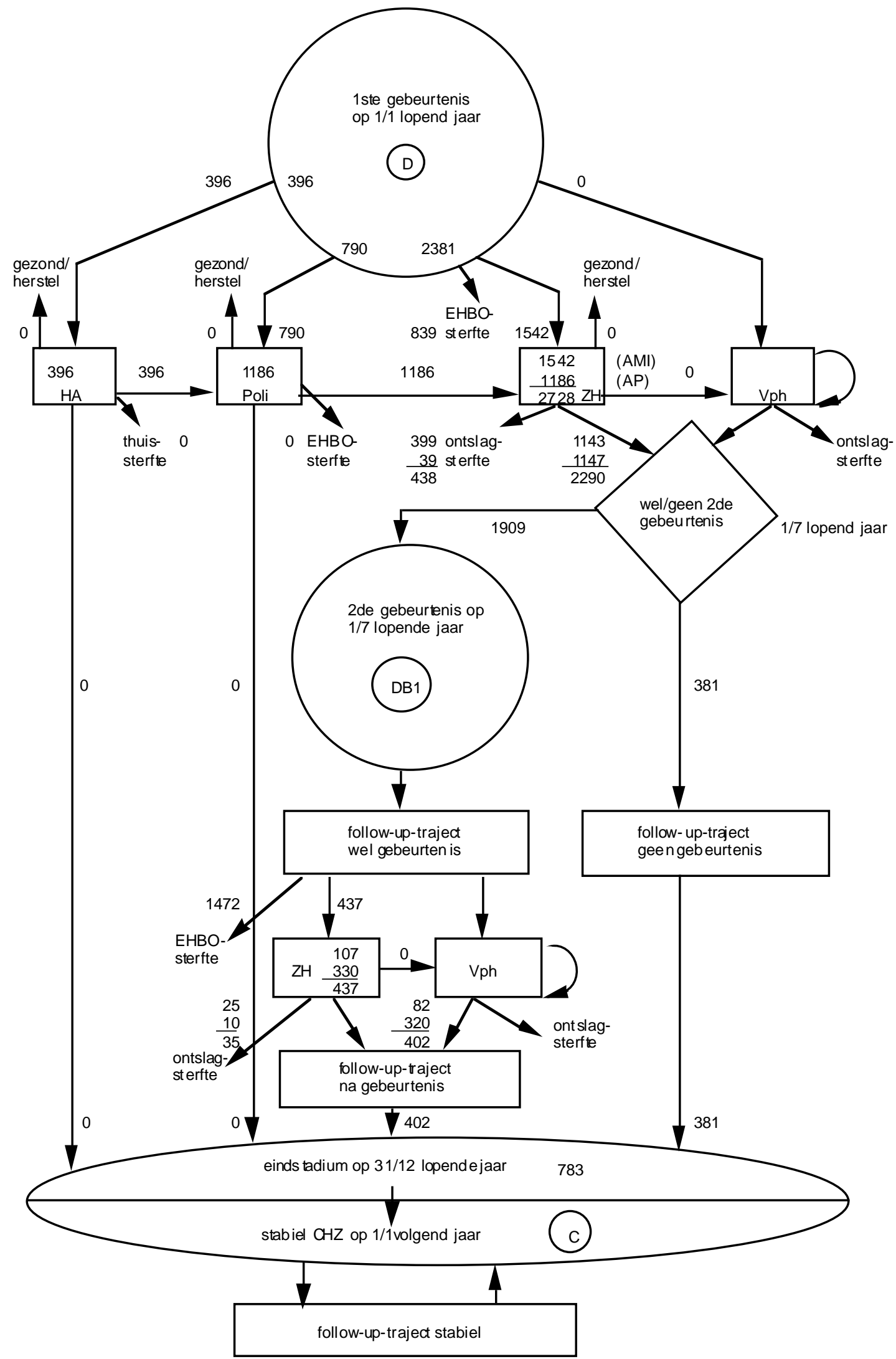

Figuur 9: Zorgmodel IVM/CHZ/D (V) 


\section{Geraadpleegde literatuur}

Bonneux L., Barendregt J.J., Meeter K, Bonsel G, Maas PJ van der. Estimating clinical morbidity due to ischemic heart disease and congestive heart failure. American Journal of Public Health 1994, 84, 20-28.

Koopmanschap, M.A., Roijen, L. van, Bonneux, L. Kosten van ziekten in Nederland. MGZ, nr. 91-03, 1991.

SIG (Stichting Informatiecentrum Gezondheidszorg). Documentatie met betrekking tot 1993. SIG-zorginformatie 1995.

Vrieze O.J., Boas G.M., Janssen, J.H.A.. Een simulatiemodel voor Toekomst Analyse van Coronaire Hartziekten. Utrecht: Jan van Arkel, 1994. 